\title{
MODUL STEM BERBASIS PEMECAHAN MASALAH DENGAN TEMA RUMAH DOME
}

\author{
Ziyyan Alieffia Alfika \\ Tantri Mayasari \\ Erawan Kurniadi \\ Progam Studi Pendidikan Fisika, Universitas PGRI Madiun \\ Email: ziyyan.alfika17@gmail.com
}

\begin{abstract}
This study aims to describe in detail the results of the development of a problem-solving STEM module with the theme of the dome house, and explain the results of the improvement after the use of the module. STEM is an approach that combines science, technology, engineering, and Mathematics into a single discipline that is able to realize learning by presenting real problems in everyday life. The STEM module based on the problem-solving ability developed raised the theme of the dome house, which has a function as an earthquakeresistant house which was used as a reconstruction of post-earthquake housing and is permanent, economical, and efficient. Solving problems is one part of high-level thinking, as well as a form of action in solving problems that utilize the knowledge they have. Indicator of achievement of problem solving is analyzing the problem, making a plan for its completion, carrying out planning, and checking again. The development method applied is Research and Development. This module is validated by 5 experts, the results show that the module is very feasible to use. The module was tested on research subjects totaling 20 eighth grade students. The results show that the highest increase in students' problem-solving ability after the implementation of the module is the indicator carrying out the plan with n-gain 0.40, while the lowest increase in the indicator understands the problem with n-gain 0.22. Overall, the STEM module that was developed was able to improve the problem solving ability of state Islamic junior high school students.
\end{abstract}

Keywords: STEM module, home dome, problem solving

\section{PENDAHULUAN}

Keterampilan abad 21 menjadi poin menarik yang acap kali dibahas dan menjadi perhatian global
Perkembangan abad 21 ditandai dengan kemajuan teknologi serta dituntutnya kesiapan suatu bangsa dalam persaingan global dengan peningkatan keterampilan berpikir 
Z, A, Alfika., T, Mayasari., E, Kurniadi. - Modul STEM Berbasis ...

tingkat tinggi. Ellis menyatakan bahwa salah satu cakupan dari keterampilan berpikir tingkat tinggi adalah keterampilan pemecahan masalah (Carson, 2007).

Memecahkan masalah dapat didefinisikan sebagai suatu tindakan dalam menuntaskan persoalan seharihari maupun lainnya serta membuat keputusan secara cermat, tepat, selaras, rasional dan mempertimbangkannya dari beragam sudut pandang (Pistany, Sunarno, \& Maridi, 2015; Polya, 1971). Kemampuan memecahkan masalah berfungsi dalam memberi solusi atau penyelesaian secara inovatif dalam menghadapi persoalan-persoalan global, sehingga keterampilan memecahkan masalah jadi salah satu tolak ukur yang patut dimiliki siswa abad 21 supaya dapat bersaing secara maksimal (The Partnership for 21st Century Skills, 2009). Hal tersebut juga dikemukakan oleh Hidayat, et al (2017) dimana kemampuan memecahkan masalah merupakan salah satu keterampilan pendidikan dalam abad 21.

$$
\text { Poyla (1971) menyatakan }
$$
indikator pencapaian dari memecahan masalah yakni memahami/ menganalisis masalah, membuat perencanaan penyelesaian, melaksanakan perencanaan, serta memeriksa kembali. Namun, kesiapan Indonesia nampaknya masih memerlukan strategi khusus. Hal ini terlihat dari peringkat Indonesia berdasarkan data TIMSS (Trends International Mathematics and Science Study) selama 16 tahun berada pada negara dengan tingkat kemampuan sains rendah (IES, 2017), selain itu data dari PISA (Progamme For Student Assessment) selama 15 tahun, Indonesia juga berada dalam negara dengan kemampuan sains rendah pula. (OECD, 2016). Rendahnya tingkat kemampuan memecahkan masalah di Indonesia juga terjadi pada salah satu MTs di Kabupaten Ponorogo, yakni dengan tingkat kemampuan memecahkan masalah sebesar 50,12\% yang masuk dalam kategori rendah (Alfika \& Mayasari, 2018).

Terdapat beberapa faktor terkait rendahnya kemampuan memecahkan masalah, diantaranya dalam pembelajaran kurang membiasakan siswa untuk berpikir lebih kreatif 
dalam menyelesaikan persoalan yang berkaitan dengan masalah sehari-hari (Rostika \& Junita, 2017) serta sumber belajar yang tidak menyertakan konten pada peningkatan pemecahkan masalah pun juga menjadi pemicu utama. Hasil analisis kebutuhan dengan teknik wawancara menunjukkan jika penggunaan media pembelajaran masih terbatas pada buku paket IPA dan LKS yang belum memfasilitasi siswa dalam mengembangkan kemampuan memecahkan masalah. Materi beserta soal-soal dalam Standart Isi pada buku Paket IPA dan LKS hanya memiliki keterampilan proses sains sebesar 48\%, relatif rendah jika dibandingkan dengan soal-soal tingkat internasional seperti soal PISA sebesar 89\% (Ramadhan \& Wasis, 2013). Materi yang disajikan berdasarkan kompetensi dasar yang lengkap, urut dan sistematik. Akan tetapi, buku paket sifat penyajiannya cenderung informatif serta terfokus dengan konten bahan ajar yang cakupannya luas dan umum (Munadi, 2008).

Kondisi tersebut membuat peneliti termotivasi untuk me- ngembangkan bahan ajar pendamping yang bermanfaat untuk meningkatkan kemampuan siswa dalam memecahkan masalah. Penelitian sebelumnya yang dilakukan oleh (Aji, Hudha, \& Rismawati, 2017) dan (Pistanty, Sunarno, \& Maridi, 2015) terkait pengembangan modul IPA dalam peningkatan kemampuan memecahkan masalah, dalam penelitian tersebut solusi dalam meningkatkan kemampuan memecahkan masalah adalah dengan diterapkannya modul berbasis PBL. Penelitian tersebut harus ada pengembangan lebih lanjut terkait media pembelajaran yang lebih menarik serta inovatif dan disesuaikan tuntutan abad 21 serta kondisi lingkungan disekitar siswa sehingga akan memudahkan siswa dalam memvisualisasikan antara materi pelajaran dengan benda atau fenomena disekitarnya yang sering dijumpai. Modul sendiri adalah bahan ajar yang melatih kemandirian siswa dalam belajar, sehingga siswa memiliki keleluasaan untuk menyelesaikan kompetensi dasar lebih cepat dan terfokus pada peningkatkan kemampuan yang bisa dicapai secara maksimal (Munadi, 
2008; Majid, 2011). Peneliti dengan maraknya bencana alam berinovasi untuk mengembangkan berupa gempa bumi yang menimpa sebuah modul dengan pendekatan Indonesia, contohnya saja gempa STEM (Science, Technology, Lombok yang terjadi pada 5 Agustus Engineering, and Mathematics) yang 2018 dengan kekuatan 7,0 SR yang diintegrasikan dengan kemampuan membuat tak kurang dari 153.533 memecahkan masalah dimana erat bangunan rusak dan gempa Palu pada kaitannya dengan lingkungan sekitar. 29 September 2018 dengan kekuatan Modul yang dikembangkan berbeda dari yang lainnya karena mengintegrasikan STEM dengan kearifan lokal serta kondisi 7,4 SR, data sementara menunjukkan ada 2790 hancur (Kompas, 2018). Maka pendidikan yang sekaligus sebagai bentuk mitigasi bencana, lingkungan di sekitar siswa atau fenomena yang sering dijumpai siswa. Modul disajikan dengan mengangkat sebuah objek yang dijadikan fenomena utama pada modul berupa "rumah dome" yang lebih dikenal dengan rumah tahan gempa Yogyakarta dimana merupakan kearifan lokal dan sesuai dengan Kompetensi Dasar yang masuk dalam modul. Rumah dome berbentuk layaknya kubah dan mirip rumah igloo dari suku Eskimo yang berfungsi sebagai rumah tahan gempa dan dijadikan rekonstruksi hunian pasca gempa Yogyakarta tahun 2006 yang bersifat permanen, ekonomis, dan efisien (Saraswati, 2007; Marindrha 2018). Apalagi dibarengi akan member wawasan sejak dini kepada siswa terkait penyebab dan penanggulangan kerusakan akibat gempa (khususnya bangunan). Selain itu, aktifitas siswa pada modul dihadirkan dengan diintegrasikan pada kemampuan memecahkan masalah.

Pendekatan STEM bermakna memadukan empat elemen pembelajaran yaitu science $(S)$, technology $(T)$, engineering $(E)$, and Mathematics (M) dengan memfokuskan pada pemecahan masalah konkrit dengan menyajikan topiktopik dalam aktivitas sehari-hari yang dekat dengan siswa ataupun yang dialami oleh siswa (Subramaniam, Ahn, Fleischmann, \& Druin, 2015; 
Sari, 2017). Materi diintegrasikan langsung dengan fenomena disekitar yang akan memudahkan siswa dalam memecahkan masalah. Didukung juga penelitian dari (Permanasari, 2016; Adlim, Saminan, \& Ariestia, 2015) bahwa implementasi pendekatan pembelajaran STEM pada modul efektif dalam meningkatkan kemampuan sains, dimana kemampuan memecahkan masalah menjadi salah satu cakupan dari keterampilan sains (Nugraheni \& Suyanto, 2017). Pendekatan STEM memberikan peluang kepada guru untuk menanamkan konsep, prinsip dan teknik dari sains, teknologi, engineering, dan matematika secara terintegrasi untuk mengembangan suatu produk dalam kehidupan seharihari. Pendekatan ini lebih tepat dikenalkan sejak dini (tingkat SMP) sehingga pemahaman siswa ditingkat lanjut akan mengarah pada prosesnya.

Pengembangan modul STEM ini diharapkan mampu memudahkan peserta didik dalam pembelajaran yang mengharuskannya untuk berpikir kritis, kreatif dan mampu memecahkan masalah secara mandiri sedini mungkin yang dikaitkan dengan kehidupan sehari-hari, Modul ini bisa dijadikan pendamping LKS sebagai sarana untuk lebih menunjang saat kegiatan belajar mengajar berlangsung, selain itu modul juga bisa menjadi sumber untuk memperbaiki kualitas pendidikan yang terintegrasi dengan kemampuan memecahkan masalah sehingga dapat meningkatkan kompetensi Indonesia dalam skala Internasional.

\section{METODE}

Penelitian Modul STEM berbasis pemecahan masalah ini dikembangkan dengan metode $R \& D$ dan dipaparkan pada penelitian ini secara deskriptif kualitatif dengan pendekatan kuantitatif, yang memiliki tujuan guna menggambarkan secara rinci hasil pengembangan dari modul STEM serta peningkatan kemampuan memecahkan masalah. Sebelum modul STEM berbasis kearifan lokal pada rumah dome diterapkan dalam pembelajaran, terlebih dahulu modul divalidasi. Validasi modul STEM ini melibatkan lima orang ahli yang terdiri dari dosen dan guru fisika. Teknik untuk menganalisis validasi 
ahli menggunakan persamaan dari Lawshe (1975). Penelitian dilakukan di MTs N 5 Ponorogo pada semester genap 2017/2018. Sampel penelitian ini ialah siswa kelas VIII F dengan jumah 20 siswa diambil secara rundom. Desain penelitian ini menerapkan uji awal dan uji akhir (pretest-postest). Instrumen yang diterapkan pada pengambilan data yaitu tes keterampilan pemecahan masalah dengan soal esay sebanyak lima buah soal yang disesuaikan dengan indikator kemampuan memecahkan masalah, yaitu memahami/menganalisis masalah, membuat perencanaan penyelesaian, melaksanakan perencanaan, serta memeriksa kembali. Pengukuran kemampuan memecahkan masalah berdasarkan hasil pre-test dan postest serta analisis n-gain.

\section{HASIL DAN PEMBAHASAN}

Modul STEM pada rumah dome berbasis memecahkan masalah ini dikembangkan dengan model ADDIE (Analysis, Design, Development, Implementation and Evaluation). Melewati proses analisis kebutuhan, proses pembuatan desain, pengembangan modul, implementasi dikelas serta evaluasi dari semua tahap. Berdasarkan hasil evaluasi, modul direvisi sedemikian rupa untuk memenuhi kebutuhan yang belum tercapai secara maksimal setelah proses implementasi. Penyajian modul yang mengintegrasikan STEM dan terfokus pada satu objek yang berkaitan dengan materi getaran, gelombang dan bunyi. Berdasarkan hasil studi pustaka serta penelitian pendahuluan, dipilihlah "rumah dome" sebagai objek yang melekat dimasyarakat dan familiar untuk siswa serta sesuai dengan materi yang akan dijadikan penelitian. Berikut adalah proses pengintegrasikan STEM pada rumah dome dalam modul yang disesuaikan dengan materi getaran, gelombang dan bunyi dapat dilihat pada Gambar 1.

Rumah dome dapat dikaji dari beberapa ilmu pengetahuan. Hal ini akan mempermudah peserta didik dalam mempelajari sekaligus berberapa ilmu pengetahuan dalam satu pokok bahasan, selain itu guru mampu menjelaskan keterkaitan dari satu cabang ilmu dengan lainnya melalui pendekatan STEM dalam hal 
ini rumah dome. Selain itu, sebagai pencegahan terhadap pembangunan rumah tahan gempa kerusakan rumah atau bangunan yang atau sering di sebut dengan rumah ditimbulkan karena getaran yang teletubis atau rumah dome dijadikan hebat atau besar.

(a)

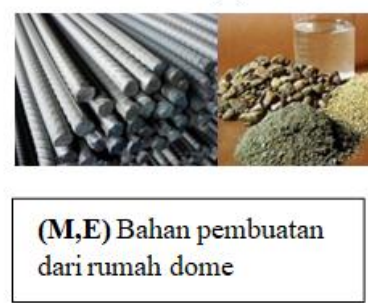

(d) (b)

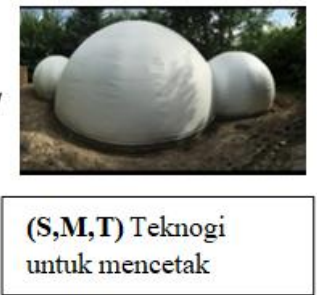

(c)

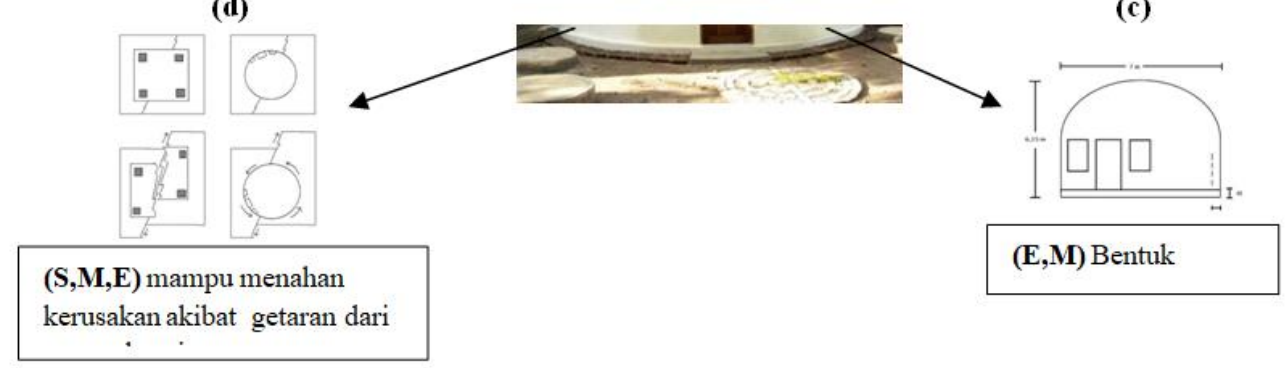

Gambar 1. Integrasi STEM Rumah dome

Jika ditinjau dari sisi material maka terdapat aspek Mathematics dan engineering. Dari sisi Mathematics persentase bahan dalam pembuatan pondasi yaitu campuran 7-15\% air, 15-20\% semen, 25-30\% pasir dan $30-50 \%$ batu yang sudah dipecah kecil. Sedangkan jika ditinjau dari sisi engineering, design/ rancangan pembuatan rumah dome (tahan gempa), bahan pembuatan, serta cara membuatnya. Selanjutnya rumah dome dibangun dengan teknologi
Airfoam atau Balon. Jika ditinjau dari sisi sains Getaran dan gelombang yang menyebabkan terjadinya gempa bumi sehingga dibutuhkan rumah tahan gempa dimana airfoam dijadikan sebagai bahan pencetaknya serta persamaan frekuensi dan periode pada getaran dan gelombang seismik $F=\frac{n}{t}$. Secara teknis, fungsi dari airfoam adalah untuk mencetak bentuk dari rumah dome. Kemudian airform tersebut diisi udara agar dapat 
membentuk setengah lingkaran. lepas dari implementasi sains dalam Airfoam, dicetak sesuai dengan besar rumah dome yang dibuat dengan bangunan yang diinginkan, diikat memperhitungkan implementasi dari pada ring beton pondasi. persamaaan cepat rambat gelombang Polyurethane disemprotkan dibagian serta mampu menahan kecepatan dalam airfoam, yang berfungsi untuk menahan bentuk dari airfoam. hembusan angin hingga $450 \mathrm{~km} / \mathrm{jam}$. Kemudian dilakukan pemasangan rangka baja secara vertikal dan horizontal, semakin besar dome, Hal tersebut bertujuan agar saat terjadinya gempa bumi, struktur/design pondasi akan semakin kecil jarak antar baja. Tahap selanjutnya adalah penyemprotan beton hingga setebal 3 inchi, setelah beton jadi, baru diberi material finishing interior.

Jika ditinjau sistem pondasi dari rumah dome dibuat sedemikian rupa dengan melingkar sehingga akan memberikan ketahanan merata pada semua bagian bangunan. Hal ini tidak mengikuti pergerakan tanah, sehingga tidak ada perlawanan/tubrukan aktivitas antara pergerakan tanah dengan konstruksi di atasnya. Manfaatnya ialah design pondasi akan mengikuti pergerakan tanah saat terjadi goncangan dari dalam bumi.

Hasil dari proses implementasi, peningkatan kemampuan memecahkan masalah terlihat seperti pada Gambar 2.

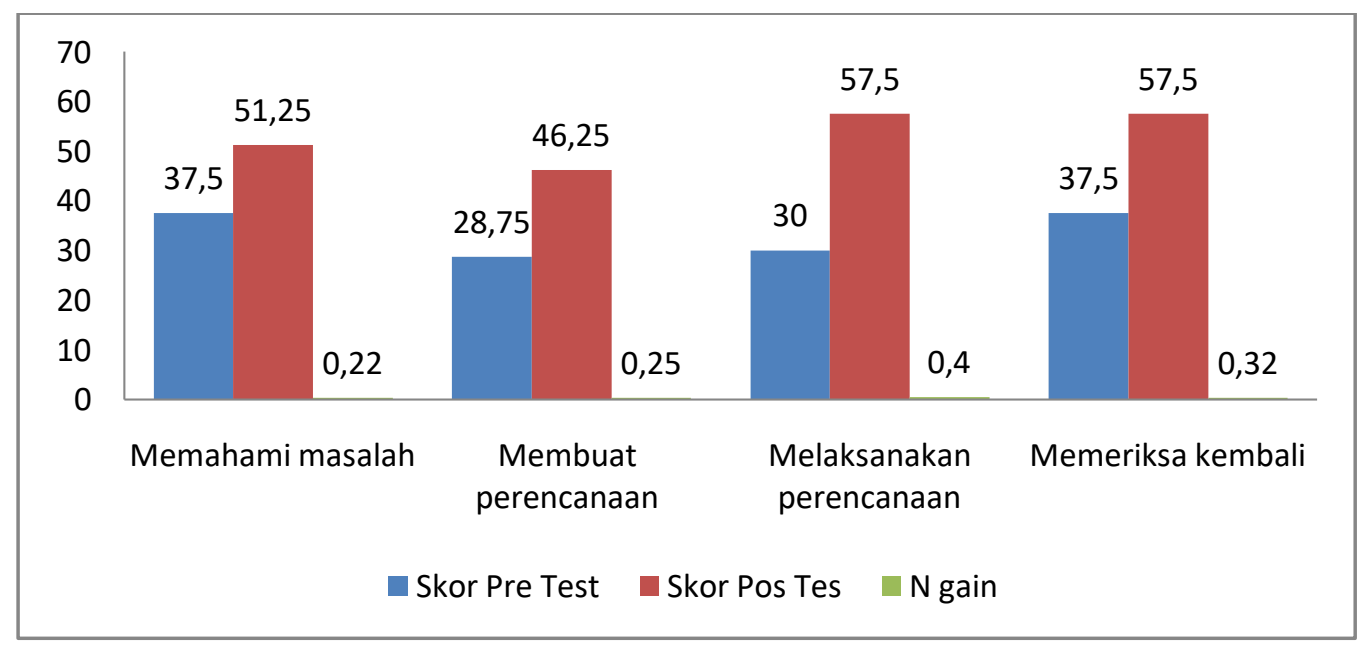

Gambar 2. Hasil pre-pos tes \& peningkatan kemampuan memecahkan masalah 
Berdasarkan data yang di sajikan pada Gambar 5. menunjukkan bahwa adanya peningkatan pada setiap indikator keterampilan pemecahan masalah. Hasilnya, keterampilan pemecahan masalah siswa sebelum penerapan modul dilihat dari empat indikator memperoleh rata-rata sebesar $33,4 \%$ termasuk dalam kategori rendah, sedangkan untuk rata-rata nilai post tes adalah $53,1 \%$ yang masuk dalam kategori cukup. Dari data tersebut diperoleh hasil analisis peningkatan kemampuan memecahkan dengan rata-rata sebesar $29 \%$ dengan n-gain 0,29 termasuk kategori rendah. Peningkatan kemampuan siswa dalam memecahkan masalah ini salah satunya disebabkan oleh fenomena yang familiar dikenal siswa, yang membuat mereka tertarik dengan pembelajaran. Hal ini serupa dengan yang diungkapkan oleh (Azizahwati, Maaruf, Yassin, \& Yuliani, 2015) jika pembelajaran yang diorientasikan dengan kearifan lokal kian menyampaikan kesan kontekstual sehingga siswa lebih sederhana dalam menginterpretasikan pelajaran yang ditekuni. Post tes dilakukan setelah diterapkannya modul dalam pembelajaran. Sebelumnya modul telah divalidasi dengan tujuan guna memperoleh informasi yang terdiri dari kritik dan saran tentang modul yang dibuat. Berdasarkan hasil validasi modul yang dilakukan oleh ahli didapatkan bahwa modul STEM yang dikembangkan dinyatakan sangat layak dengan CVI (Content Validity Index) 1.

Peningkatan kemampuan memecahkan masalah tertinggi terdapat pada indikator melaksanakan rencana yaitu nilai $n$-gain sebesar 0,4. Hal ini disebabkan karena tipe soal yang diberikan pada indikator melaksanakan rencana adalah mereview apa yang sudah dijelaskan dan diterangkan pada modul, sehingga akan memudahkan siswa karena sebelumnya sudah dipelajari. Sejalan dengan penelitian (Ambarwati, 2016), bahwa tingginya kemampuan siswa dalam melaksanakan rencana disebabkan karena siswa mampu menuliskan langkah penyelesaian masalah secara tepat. (Sugiarto, Amin, \& Yani, 2016) menyatakan bahwa melaksanakan rencana memiliki fungsi penting bagi siswa 
dalam memecahkan masalah, yaitu siswa akan belajar melaksanakan rancangan atau rencana yang telah mereka buat untuk penyelesaian dari masalah yang disajikan sehingga siswa dituntut untuk berpikir kritis dan kreatif.

Peningkatan terendah ada pada indikator memahami masalah yaitu nilai $n$-gain sebesar 0,22. Hal ini disebabkan karena soal pre dan post tes yang diberikan pada soal memahami masalah berbeda tipe, sehingga siswa kesulitan untuk memahami masalah baru yang disajikan. Sejalan dengan penelitian (Sinaga, Rahmad, \& Irianti, 2014), bahwa kurangnya keterampilan siswa ketika memahami masalah disebabkan karena siswa kurang cakap dalam menginterpretasikan segala sesuatu yang diketahui serta ditanyakan pada soal, dan siswa kurang fokus pada masalah yang disajikan. (Polya, 1971) menyatakan bahwa memahami masalah berfungsi sebagai titik awal dalam pengerjaan soal. Indikator ini sangat penting dimiliki siswa sejak dini sehingga siswa akan mampu mengidentifikasi apa saja yang diketahui dan ditanyakan dari permasalahan yang diberikan yang diberikan. Dari 20 siswa yang mengikuti pembelajaran, ada 13 siswa masuk rumpun sedang dan 7 siswa pada rumpun rendah.

\section{PENUTUP}

\section{Kesimpulan}

Produk dari penelitian penembangan ini menghasilkan modul yang mengintegrasikan materi getaran gelombang dan bunyi dengan pendekatan STEM. Modul disajikan dengan mengangkat sebuah objek yang dijadikan fenomena utama pada modul berupa "rumah dome" yang lebih dikenal dengan rumah tahan gempa Yogyakarta atau dimana merupakan kearifan lokal dan sesuai dengan Kompetensi Dasar yang masuk dalam modul. Selain itu, aktifitas siswa pada modul dihadirkan dengan diintegrasikan pada indikator ketercapaian memecahkan masalah, yaitu "memahami masalah" dari persoalan yang disediakan, "membuat perencanaan penyelesaian, "melaksanakan perencanaan" dan "memeriksa kembali" rencana yang dilaksanakan sehingga melatih siswa untuk meningkatkan kemampuan 
tersebut. Peningkatan kemampuan memecahkan masalah diukur dari pre dan pos tes masuk pada kelompok rendah dengan rata-rata $n$-gain 0,29 . Peningkatan tertinggi pada indikator melaksanakan rencana dengan $n$-gain 0,4 . Hal ini disebabkan karena tipe soal yang diberikan pada indikator melaksanakan rencana adalah mereview apa yang sudah dijelaskan dan diterangkan pada modul, sehingga akan memudahkan siswa karena sebelumnya sudah dipelajari. Peningkatan terendah ada pada indikator memahami masalah dengan $n$-gain 0,22. Hal ini disebabkan karena soal pre dan post tes yang diberikan pada soal memahami masalah berbeda, sehingga siswa kesulitan untuk memahami masalah baru yang disajikan. Sebelumnya modul telah divalidasi olehlima orang ahli dan didapatkan CVI 1 dengan kategori sangat layak.

\section{Saran}

Hasil penelitian memperlihatkan bahwa peningkatan keterampilan pemecahan masalah siswa rendah, padahal modul yang diberikan sudah dinyatakan layak oleh validator. Hal ini disebabkan waktu dilakukannya penelitian terbatas karena mendekati UAS dan hanya melewati dua kali pertemuan. Kondisi tersebut menyebabkan penyampaian isi modul serta pengerjaan soal pemecahan masalah oleh siswa kurang maksimal sehingga hasil peningkatanya rendah. Untuk menghasilkan $n$-gain yang lebih baik, perlu dilakukan uji implementasi dengan durasi waktu yang lebih lama kurang lebih enam kali pertemuan sesuai dengan konten dan isi modul. Selain itu, perlu ditingkatkannya jumlah soal tentang pemecahan masalah sehingga siswa terbiasa menyelesaikan persoalan secara tanggap dan inovatif untuk menuntaskan persoalan yang mereka hadapi serta dituntut untuk mandiri.

\section{DAFTAR PUSTAKA}

Adlim, M., Saminan, \& Ariestia, S. (2015). Pengembangan Modul STEM Terintegrasi Kewirausahaan untuk Meningkatkan Keterampilan Proses Sains di SMA Negeri 4 Banda Aceh. Jurnal Pendidikan Sains Indonesia, 112-121.

Aji, S. D., Hudha, M. N., \& Rismawati, A. Y. (2017). Pengembangan Modul Pembelajaran Fisika Berbasis 
Z, A, Alfika., T, Mayasari., E, Kurniadi. - Modul STEM Berbasis ...

Problem Based Learning untuk

Meningkatkan Kemampuan

Pemecahan Masalah Fisika.

Science Education Journal , 116.

Alfika, Z. A., \& Mayasari, T. (2018). Profil kemampuan memecahkan masalah pelajaran fisika siswa MTs. Quantum th25 Seminar Nasional Fisika dan Pendidikan Fisika , 1-7. Yogyakarta: Universsitas Ahmad Dahlan. Ambarwati, M. (2016). Analisis Kemampuan Pemecahan Masalah dalam Strategi Think Talk Write (TTW). Jurnal Pedagogia , 241-244.

Ambarwati, M. (2016). Analisis Kemampuan Pemecahan Masalah dalam Strategi Think Talk Write (TTW). Jurnal Pedagogia , 241-244.

Azizahwati, Maaruf, Z., Yassin, R. M., \& Yuliani, E. (2015). Pengembangan Modul Pembelajaran Fisika SMA Berbasis Kearifan Lokal untuk Meningkatka Hasil Belajar Siswa. Prosiding Pertemuan Ilmiah XXXIX HFI (pp. 70-73). Yogyakarta: HFI Jateng dan DIY.

Carson, J. (2007). A Problem With Problem Solving: Teaching Thinking Without Teacing Knowledge. The Matematics Educator Journal , 1-2.

Hidayat, S. R., Setyadin, A. H., Hermawan, Kaniawati, I., Suhendi, E., Siahaan, P., et al. (2017). Pengembangan Instrumen Tes Keterampilan Pemecahan Masalah pada Materi Getaran, Gelombang, dan Bunyi. Jurnal Penelitian \&
Pengembangan Pendidikan

Fisika , 1-10.

IES. (2017). Highlights From TIMSS and TIMSS Advanced 2015. Retrieved Mei 25, 2018, from IES National Center for Education Statistics: http://nces.ed.gov/pubs2017/tim ss

Kompas. (2018, Oktober 2). Kompas.com. Retrieved Oktober 1, 2018, from https://properti.kompas.com/rea d/2018/10/01/210500421/datasementara-2.790-rumah-rusakakibat-gempa-palu

Lawshe, C. H. (1975). A quantitative approach to content validity. Personnel Psychology. 28(4). 563-575.

https:/doi.org/10.1111/J.17446570.1975.TB01393.X.

Majid, A. (2011). Perencanaan Pembelajaran. Bandung: PT Remaja Rosdakarya.

Marindrha, P. P. (2018). Adaptasi Spasial pada Rumah Dome Ngelepen Sumberharjo, Prambanan, Sleman. Jurnal penelitian, INERSIA , 1-11.

Munadi, Y. (2008). Media Pembelajaran : Sebuah Pendekatan Baru. Ciputat: Gaung Persada Press.

Nugraheni, D., \& Suyanto, S. (2017). Pengaruh siklus belajar $5 \mathrm{e}$ terhadap kemampuan literasi sains pada materi sistem saraf manusia. Jurnal Prodi Pendidikan Biologi , 178-179.

OECD. (2016). PISA 2015 Result (Volume I) Excellence and Equity in Education. Paris: OECD Publications.

Permanasari, A. (2016). STEM Education:Inovasi dalam 
Pembelajaran Sains. Seminar Nasional Pendidikan Sains , 2330.

Pistanty, M. A., Sunarno, W., \& Maridi. (2015). Pengembangan Modul IPA Berbasis Problem Based Learning untuk Meningkatkan Kemampuan Memecahkan Masalah pada Materi Polusi serta Dampaknya pada Manusia dan Lingkungan Siswa Kelas XI SMK Pancasila Purwodadi. Jurnal Inkuiri , 6775.

Polya, G. (1971). How To Solve It: A New Aspect of Mathematical Method.USA. Princeton University Press, Princeton, New Jersey.

Ramadhan, D., \& Wasis. (2013). Analisis Prbandingan Level Kognitif dan Keterampilan Proses Sains dalam Standar Isi (SI), Soal Ujian Nasional (UN), Soal Trends in International Mathemtics and Science Study (TIMSS), dan Soal Programme For International Student Assessment (PISA). Jurnal Inovasi Pendidikan Fisika , 2025.

Rostika, D., \& Junita, H. (2017). Peningkatan kemampuan pemecahan masalah siswa SD dalam pembelajaran matematika dengan model diskursus multi representation (DMR). Jurnal Pendidikan Dasar, 36.

Saraswati, T. (2007). Kontroversi Rumah Dome di Nglepen, Prambanan, D.I. Yogyakarta. Dimensi Teknik Arsitektur , 17.

Sari, R. H. (2017). Pengaruh implementasi pembelajaran
STEM terhadap persepsi, sikap, dan kreativitas siswa. Prosiding Seminar Nasional MIPA , 417.

Sinaga, E. S., Rahmad, M., \& Irianti, M. (2014). Penerapan Model Pembelajaran Problem Based Learning (PBL) untuk Meningkatkan Kemampuan Memecahkan Masalah Fisika di Kelas XI IPA SMA N Teluk Kuantan. Jurnal Penelitian Pendidikan, 10-13.

Subramaniam, M., Ahn, J., Fleischmann, K., \& Druin, A. (2015). Reimagining the Role of School Libraries in STEM Education: Creating Hybrid Spaces for Exploration. Chicago Journals, 161-184.

Sugiarto, M., Amin, B. D., \& Yani, A. (2016). Studi Kemampuan Menyelesaikan Soal-Soal Fisika Menurut Langkah Pemechan Masalah Polya pada Peserta Didik XI IPA SMA Negeri 1 Baraka Kabupaten Enrekang. Jurnal Sains dan Pendidikan Fisika , 189.

The Partnership for 21ST Century Skills. 2009. The MILE Guide: Milestones For Improving Learning and Education. 